\title{
Assessment of Heavy Metal Pollution in Drinking Water Due to Mining and Smelting Activities in Ajaokuta, Nigeria
}

\author{
M. M. Orosun ${ }^{1 *}$, P. Tchokossa ${ }^{2}$, L. I. Nwankwo ${ }^{1}$, T. O. Lawal ${ }^{1}$, S. A. Bello ${ }^{1}$, S. O. Ige ${ }^{1}$ \\ ${ }^{1}$ Department of Physics, University of Ilorin, Ilorin, Nigeria. \\ ${ }^{2}$ Department of Physics, Obafemi Awolowo University, Ile-Ife, Nigeria.
}

\begin{abstract}
Mining and smelting activities are the main causes for the increasing pollution of heavy metals from water sources. The toxicity of these heavy metals from the mining, milling and smelting companies can cause harmful and even lethal effects on the human health. The objective of this study was to investigate the level of As, Cr, $\mathrm{Zn}$, $\mathrm{Mg}, \mathrm{Fe}, \mathrm{Pb}, \mathrm{Cd}, \mathrm{Cu}, \mathrm{Ag}$ and $\mathrm{Mn}$ in well and tap water and assess the degree of pollution in the study area. Atomic Absorption Spectrometry investigation was carried out on 60 samples of water (Well and Tap) collected within and outside the mining and smelting area of Ajaokuta to determine the extent of these heavy metals contamination in their drinking water. The data of heavy metal concentrations reveal that the area has been slightly contaminated with the heavy metals, with As and $\mathrm{Cr}$ having the highest level of contamination. Correlation analysis between the selected heavy metals was conducted to further investigate the relationship between the metals. The result shows that these selected metals have common pollution sources related to the mining and smelting activities in the area.
\end{abstract}

KEYWORDS: Heavy metals, atomic absorption spectrometry (AAS), smelting, pollution, well water.

[Received February 8 2016; Revised May 16 2016; Accepted June 17 2016]

\section{INTRODUCTION}

The presence of heavy metals in natural water as major cause of pollution has received considerable attention in recent years due to its potential risk to human health and ecology (WHO and UNICEF, 2011; UNICEF and WHO 2012; Olukanni et al, 2014). Mining activities has destroyed natural habitats, polluted the air, soil and water, as well as long term environmental impacts (UNEP, 1997). The toxicity of heavy metals from the mining, milling and smelting companies such as cadmium, zinc, lead, copper, manganese, magnesium, iron, arsenic, silver, chromium can have harmful and even lethal effects on the human body, depending on the concentration and rate of consumption. Water is one of the essentials that supports all forms of plant and animal life (Vanloon and Duffy, 2005; WHO, 2011) and it is generally obtained from two principal natural sources namely surface water (such as fresh water lakes, rivers, streams, etc) and ground water (such as borehole water and well water) (McMurry and Fay, 2004; Mendie, 2005).

Water has unique chemical properties due to its polarity and hydrogen bond which means it is able to dissolve, absorb, adsorb or suspend many different compounds (WHO, 2008). Thus, in nature, the water is not pure as it acquires contaminants from its surrounding and those arising from humans and animals as well as other biological activities (Mendie, 2005). One of the most important environmental issues today is ground water contamination (Vodela et al., 1997; WHO, 2011; Nwankwo, 2013; Lawrence, 2014), majorly heavy metals receive particular concern considering

*Corresponding author's e-mail address: muyiwaorosun@yahoo.com their strong toxicity even at low concentrations (Marcovecchio et al., 2007). Heavy metals are elements having atomic weights between 63.546 and 200.590 amu and a specific gravity greater than 4.0 i.e. at least 5 times that of water. They exist in water in colloidal, particulate and dissolved phases (Adepoju-Bello et al., 2009) with their occurrence in water bodies being either of natural origin (e.g. eroded minerals within sediments, leaching of ore deposits and volcanism extruded products) or of anthropogenic origin (i.e. industrial or domestic effluents, harbor channel dredging) (Marcovecchio et al., 2007).

Heavy metal can cause serious health effects with varied symptoms depending on the nature and quantity of the metal ingested (Adepoju-Bello and Alabi, 2005). They produce their toxicity by forming complexes with proteins, in which carboxylic acid $(-\mathrm{COOH})$, amine $\left(-\mathrm{NH}_{2}\right)$, and thiol $(-\mathrm{SH})$ groups are involved. These modified biological molecules lose their ability to function properly and result in the malfunction or death of cells. When metals bind to these groups, they inactivate important enzyme systems or affect protein structure, which is linked to the catalytic properties of enzymes. This type of toxin may also cause the formation of radicals which are dangerous chemicals that cause the oxidation of biological molecules. The most common heavy metals that humans are exposed to are Arsenic, Cadmium, and Lead. Arsenic exposure can cause among other illness or symptoms cancer, abdominal pain and skin diseases. Cadmium exposure produces kidney damage and hypertension. Lead is a commutative poison and a possible human carcinogen (Bakare-Odunola, 2005). In addition, Lead may cause the 
development of autoimmunity in which a person's immune system attacks its own cells. This can lead to joint diseases and ailment of the kidneys, circulatory system and neurons. At higher concentrations, Lead can cause irreversible brain damage.

In Nigeria today, the use of ground water has become an agent of development because the government is unable to meet the ever increasing water demand. Thus, inhabitants have had to look for alternative ground water sources such as shallow wells and boreholes (Nwankwo et al, 2013; Olukanni and Ugwu, 2013). The quality of these ground water sources are affected by the characteristics of the media through which the water passes on its way to the ground water zone of saturation (Adeyemi et al., 2007). Thus, the heavy metals discharged by the mining and milling activity of Ajaokuta Steel Company can result in a steady rise in contamination of ground water. The focus of this work is to assess the level of concentration of some selected heavy metals (Cadmium Cd, Arsenic As, Chromium Cr, Lead $\mathrm{Pb}$, Copper $\mathrm{Cu}$, and other elements like Magnesium Mg, Manganese Mn, and Iron Fe) of water samples collected within Ajaokuta Steel Company and derived the potential health risks associated with the people living around the environment.

\section{MATERIALS AND METHODS}

\section{a. Study Area}

Ajaokuta is located between latitude of $6.58^{\circ} \mathrm{N}$ to $6.70^{\circ} \mathrm{N}$ and longitude $8.80^{\circ} \mathrm{E}$ and $8.89^{\circ} \mathrm{E}$ in Kogi State. It has area of $1,362 \mathrm{~km}^{2}$ and a population of 122,321 at the 2006 census. It is the home of the multi-billion dollar steel rolling Mill. The steel project is located on 24, 000 hectares of sprawling greenfiled land-mass. The steel plant itself is built on 800- hectares of land using the tested Blast - furnace - Basic Oxygen Furnace route for steel production.

\section{b. Sample Collection and Preparation}

A total of 60 water samples were collected and investigated. Comprises of 24 samples of well-water and 24 samples of tap-water within the study area and 12 sample of well and tap water each outside the study area. The water samples were collected in a clean polyethylene bottles, because glass bottles absorb metals and therefore will cause inaccuracy in analysis. The water was filtered through a 0.45 micrometer membrane filter as soon as possible after collection. For the digestion, $1 \mathrm{~L}$ of each sample was measured into a clean digestion flask. $9 \mathrm{ml}$ of concentrated $\mathrm{HNO}_{3}$ and $3 \mathrm{ml}$ of concentrated $\mathrm{HCl}$ was added into the sample in the digestion flask (USEPA, 1986; Bader, 2011). The whole samples was heated in a hot plate until all the brownish fumes was expelled out (Nitrogenous Compound) which confirm that the sample is digested and the samples was allowed to cool at room temperature. A few millilitres of distilled water was added and the mixture was filtered into $25 \mathrm{ml}$ standard flask and it was transferred into plastic reagent bottle for Atomic Absorption Spectrometry (AAS).

The Atomic Absorption Spectrometry is a spectroanalytical procedure for the quantitative determination of chemical elements using the absorption of optical radiation (light) by free atoms in the gaseous state. The technique measures the concentrations of elements in digested samples down to parts per million (ppm) in a sample. The Atomic Absorption Spectrometry was carried out at ROTAS Soil-Lab in Ibadan using Buck Scientific Model 210 VGP Atomic Absorption Spectrophotometer.

\section{c. Results and Discussion}

The results of the analysis are presented in Tables $1-4$. Current drinking water quality guidelines (in $\mathrm{ppm}$ or $\mathrm{mg} / \mathrm{L}$ ) for the selected heavy metals published by several organizations, committees or agencies throughout the world are given in Table 3. Figures 2 and 3 gives a comparative chart for the mean results obtained from the analysis.

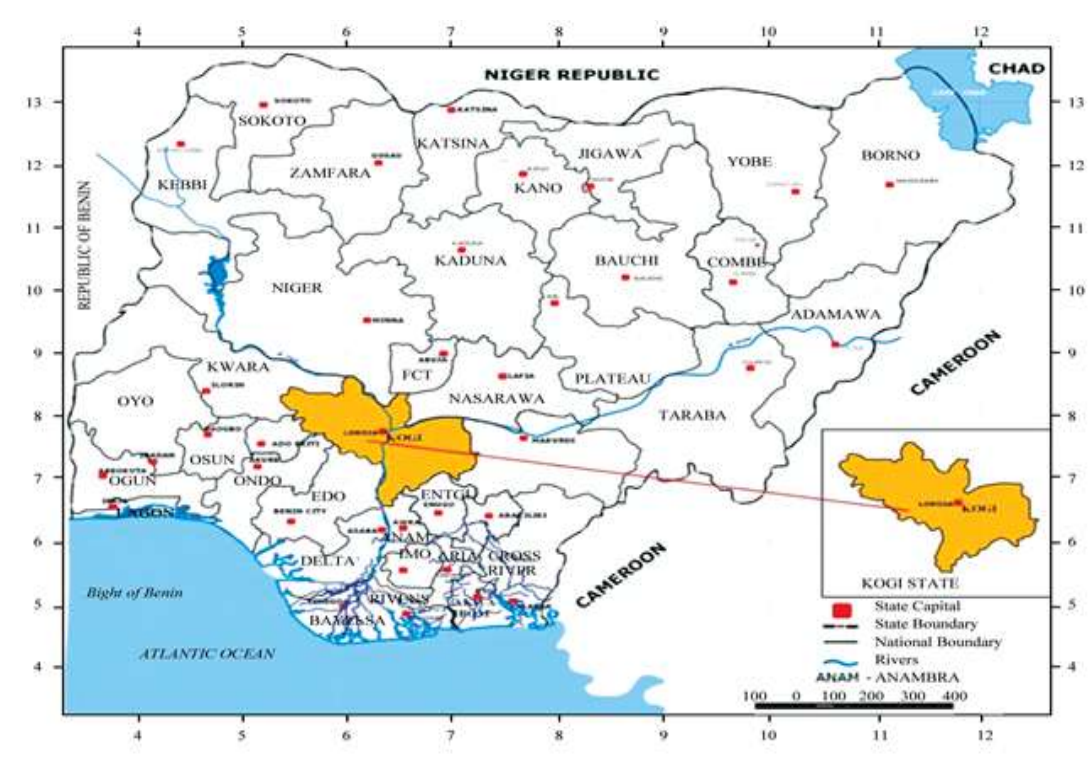

Figure 1: Map of Nigeria showing the location of Kogi State.

Source: Kogi State Ministry of Land and Environment, 2008 
Table 1: Concentration of Heavy Metals of Well-Water Samples Collected within the Study Area in ppm.

\begin{tabular}{|c|c|c|c|c|c|c|c|c|c|c|}
\hline Sample & $\mathrm{Mg}$ & $\mathrm{Mn}$ & $\mathrm{Cu}$ & $\mathrm{Zn}$ & $\mathrm{Fe}$ & $\mathrm{Pb}$ & $\mathrm{Cd}$ & $\mathrm{Ag}$ & As & $\mathrm{Cr}$ \\
\hline $\mathrm{W}_{1}$ & 1.27 & ND & 0.05 & 1.34 & 0.14 & 0.40 & ND & 0.01 & 24.06 & 13.75 \\
\hline $\mathrm{W}_{2}$ & 1.22 & ND & 0.06 & 1.23 & 0.20 & 0.21 & 0.01 & ND & 21.09 & 13.38 \\
\hline $\mathrm{W}_{3}$ & 1.17 & ND & 0.07 & 1.46 & 0.27 & 0.15 & 0.03 & 0.01 & 14.02 & 13.00 \\
\hline $\mathrm{W}_{4}$ & 1.62 & ND & 0.02 & 1.53 & 0.95 & 0.14 & 0.02 & 0.02 & 37.50 & 7.37 \\
\hline $\mathrm{W}_{5}$ & 1.25 & ND & 0.04 & 1.69 & 0.75 & 0.41 & 0.06 & 0.02 & 27.45 & 15.80 \\
\hline $\mathrm{W}_{6}$ & 1.39 & ND & 0.06 & 1.67 & 0.81 & 0.50 & 0.12 & $\mathrm{ND}$ & 30.40 & 18.91 \\
\hline $\mathrm{W}_{7}$ & 1.82 & ND & 0.07 & 1.87 & 1.01 & 0.52 & 0.16 & 0.02 & 37.60 & 18.98 \\
\hline $\mathrm{W}_{8}$ & 1.62 & ND & 0.05 & 1.62 & 0.92 & 0.42 & 0.08 & ND & 31.42 & 16.03 \\
\hline $\mathrm{W}_{9}$ & 1.24 & ND & 0.02 & 1.46 & 0.48 & 0.20 & 0.04 & ND & 21.25 & 13.04 \\
\hline $\mathrm{W}_{10}$ & 1.42 & ND & 0.05 & 1.81 & 0.76 & 0.31 & 0.06 & ND & 24.05 & 15.82 \\
\hline $\mathrm{W}_{11}$ & 1.61 & ND & 0.06 & 1.78 & 0.96 & 0.24 & 0.05 & $\mathrm{ND}$ & 27.42 & 16.68 \\
\hline $\mathrm{W}_{12}$ & 1.12 & ND & 0.02 & 1.23 & 0.28 & 0.14 & 0.02 & $\mathrm{ND}$ & 16.02 & 12.64 \\
\hline $\mathrm{W}_{13}$ & 1.64 & ND & 0.06 & 1.66 & 0.92 & 0.32 & 0.06 & 0.02 & 26.05 & 16.23 \\
\hline $\mathrm{W}_{14}$ & 1.62 & ND & 0.05 & 1.53 & 0.87 & 0.32 & 0.06 & $\mathrm{ND}$ & 24.52 & 14.66 \\
\hline $\mathrm{W}_{15}$ & 1.54 & ND & 0.04 & 1.45 & 0.69 & 0.23 & 0.05 & $\mathrm{ND}$ & 21.44 & 13.78 \\
\hline $\mathrm{W}_{16}$ & 1.43 & ND & 0.04 & 1.32 & 0.62 & 0.20 & 0.04 & $\mathrm{ND}$ & 20.06 & 13.04 \\
\hline $\mathrm{W}_{17}$ & 1.33 & ND & 0.03 & 1.42 & 0.58 & 0.12 & 0.02 & 0.01 & 18.42 & 12.04 \\
\hline $\mathrm{W}_{18}$ & 1.52 & ND & 0.03 & 1.56 & 0.52 & 0.16 & 0.02 & 0.01 & 20.22 & 13.46 \\
\hline $\mathrm{W}_{19}$ & 1.45 & ND & 0.03 & 1.46 & 0.48 & 0.12 & 0.01 & 0.01 & 18.46 & 12.42 \\
\hline $\mathrm{W}_{20}$ & 1.17 & ND & 0.02 & 1.38 & 0.37 & 0.12 & 0.01 & 0.01 & 16.56 & 12.02 \\
\hline $\mathrm{W}_{21}$ & 1.61 & ND & 0.06 & 1.63 & 0.81 & 0.22 & 0.04 & 0.02 & 27.64 & 16.78 \\
\hline $\mathrm{W}_{22}$ & 1.69 & ND & 0.07 & 1.86 & 0.92 & 0.34 & 0.06 & 0.02 & 34.68 & 17.48 \\
\hline $\mathrm{W}_{23}$ & 1.61 & ND & 0.06 & 1.76 & 0.81 & 0.32 & 0.06 & 0.02 & 31.78 & 16.04 \\
\hline $\mathrm{W}_{24}$ & 0.98 & ND & 0.02 & 1.29 & 0.28 & 0.14 & 0.02 & 0.01 & 14.54 & 10.22 \\
\hline Min & 0.98 & NA & 0.02 & 1.23 & 0.14 & 0.12 & NA & NA & 14.02 & 7.37 \\
\hline Max & 1.82 & NA & 0.07 & 1.87 & 1.01 & 0.5 & 0.16 & 0.02 & 37.60 & 18.98 \\
\hline Median & 1.44 & NA & 0.05 & 1.53 & 0.72 & 0.22 & 0.04 & 0.02 & 24.06 & 13.77 \\
\hline Mean & 1.43 & NA & 0.05 & 1.54 & 0.64 & 0.25 & 0.05 & 0.02 & 24.44 & 14.32 \\
\hline SD & 0.22 & NA & 0.02 & 0.19 & 0.27 & 0.11 & 0.04 & 0.01 & 6.91 & 2.70 \\
\hline
\end{tabular}

NA $=$ Not Available

$\mathrm{ND}=$ Not Detectable

Table 2: Concentration of Heavy Metals of Well-Water Samples Collected outside the Study Area in ppm.

\begin{tabular}{ccccccccccc}
\hline Sample & $\mathbf{M g}$ & $\mathbf{M n}$ & $\mathbf{C u}$ & $\mathbf{Z n}$ & $\mathbf{F e}$ & $\mathbf{P b}$ & $\mathbf{C d}$ & $\mathbf{A g}$ & $\mathbf{A s}$ & $\mathbf{C r}$ \\
\hline $\mathbf{O W}_{\mathbf{1}}$ & 0.23 & ND & ND & 0.10 & 0.10 & ND & ND & ND & 8.02 & 4.25 \\
$\mathbf{O W}_{\mathbf{2}}$ & 0.26 & ND & ND & 0.25 & 0.10 & ND & ND & ND & 10.00 & 8.26 \\
$\mathbf{O W}_{\mathbf{3}}$ & 0.18 & ND & ND & 0.20 & 0.20 & ND & ND & ND & 6.16 & 6.42 \\
$\mathbf{O W}_{\mathbf{4}}$ & 0.22 & ND & ND & 0.14 & ND & 0.01 & ND & ND & 13.80 & 8.62 \\
OW $_{\mathbf{5}}$ & 0.25 & ND & ND & 0.16 & 0.10 & ND & ND & ND & 9.22 & 8.02 \\
OW $_{\mathbf{6}}$ & 0.15 & ND & ND & 0.26 & 0.10 & 0.01 & ND & ND & 8.60 & 6.04 \\
Min & 0.15 & NA & NA & 0.10 & 0.10 & 0.01 & NA & NA & 6.16 & 4.25 \\
Max & 0.26 & NA & NA & 0.26 & 0.20 & 0.01 & NA & NA & 13.80 & 8.62 \\
Median & 0.23 & NA & NA & 0.18 & 0.10 & 0.01 & NA & NA & 8.91 & 7.22 \\
Mean & 0.22 & NA & NA & 0.18 & 0.12 & 0.01 & NA & NA & 9.30 & 6.94 \\
SD & 0.04 & NA & NA & 0.06 & 0.04 & 0.00 & NA & NA & 2.56 & 1.67 \\
\hline
\end{tabular}


Table 3: Concentration of Heavy Metals of Tap-Water Samples Collected within the Study Area in ppm.

\begin{tabular}{|c|c|c|c|c|c|c|c|c|c|c|}
\hline Sample & $\mathbf{M g}$ & Mn & $\mathbf{C u}$ & $\mathbf{Z n}$ & $\mathrm{Fe}$ & $\mathbf{P b}$ & Cd & Ag & As & $\mathrm{Cr}$ \\
\hline$T_{1}$ & 5.65 & 0.06 & $\mathrm{ND}$ & 0.09 & 0.07 & 0.13 & 0.01 & ND & 9.70 & 8.82 \\
\hline $\mathbf{T}_{2}$ & 3.39 & 0.08 & $\mathrm{ND}$ & 0.68 & 0.03 & 0.57 & $\mathrm{ND}$ & $\mathrm{ND}$ & 10.00 & 7.30 \\
\hline $\mathbf{T}_{3}$ & 2.18 & 0.19 & 0.01 & 0.04 & 0.50 & 0.11 & 0.02 & 0.01 & 11.80 & 13.28 \\
\hline $\mathbf{T}_{4}$ & 3.64 & 0.10 & ND & 0.32 & 0.30 & 0.34 & $\mathrm{ND}$ & $\mathrm{ND}$ & 9.75 & 11.20 \\
\hline $\mathbf{T}_{5}$ & 3.80 & 0.09 & ND & 0.14 & 0.08 & 0.18 & 0.01 & $\mathrm{ND}$ & 12.25 & 10.10 \\
\hline$T_{6}$ & 3.78 & 0.14 & ND & 0.35 & 0.22 & 0.30 & 0.02 & $\mathrm{ND}$ & 9.50 & 9.30 \\
\hline $\mathbf{T}_{7}$ & 3.34 & 0.08 & $\mathrm{ND}$ & 0.36 & 0.36 & 0.38 & 0.02 & ND & 9.27 & 9.04 \\
\hline $\mathbf{T}_{8}$ & 3.42 & 0.08 & 0.01 & 0.42 & 0.38 & 0.40 & 0.02 & $\mathrm{ND}$ & 10.22 & 10.10 \\
\hline $\mathbf{T}_{9}$ & 5.02 & 0.12 & $\mathrm{ND}$ & 0.71 & 0.51 & 0.58 & 0.02 & ND & 9.02 & 9.32 \\
\hline $\mathbf{T}_{10}$ & 4.04 & 0.14 & ND & 0.61 & 0.42 & 0.41 & 0.02 & ND & 12.04 & 13.24 \\
\hline $\mathbf{T}_{11}$ & 4.12 & 0.18 & ND & 0.60 & 0.43 & 0.38 & ND & 0.01 & 11.28 & 12.04 \\
\hline $\mathbf{T}_{12}$ & 3.78 & 0.12 & ND & ND & 0.38 & 0.28 & ND & 0.01 & 9.46 & 10.22 \\
\hline $\mathbf{T}_{13}$ & 3.08 & 0.16 & 0.01 & ND & 0.31 & 0.32 & $\mathrm{ND}$ & $\mathrm{ND}$ & 9.89 & 9.06 \\
\hline $\mathbf{T}_{14}$ & 3.46 & 0.13 & ND & ND & 0.30 & 0.34 & ND & ND & 9.28 & 9.24 \\
\hline $\mathbf{T}_{15}$ & 3.24 & 0.12 & ND & 0.36 & 0.32 & 0.28 & 0.02 & $\mathrm{ND}$ & 9.46 & 9.28 \\
\hline $\mathbf{T}_{16}$ & 4.12 & 0.12 & ND & 0.42 & 0.41 & 0.40 & 0.02 & $\mathrm{ND}$ & 10.29 & 11.04 \\
\hline $\mathbf{T}_{17}$ & 3.39 & 0.18 & ND & ND & 0.31 & 0.29 & ND & $\mathrm{ND}$ & 10.08 & 10.87 \\
\hline $\mathbf{T}_{18}$ & 3.64 & 0.12 & 0.01 & ND & 0.36 & 0.32 & ND & 0.01 & 9.27 & 9.68 \\
\hline$T_{19}$ & 3.64 & 0.16 & ND & 0.24 & 0.36 & 0.34 & 0.01 & ND & 9.66 & 10.04 \\
\hline $\mathbf{T}_{20}$ & 2.98 & 0.14 & ND & 0.04 & 0.28 & 0.12 & ND & ND & 9.46 & 9.06 \\
\hline $\mathbf{T}_{21}$ & 3.56 & 0.10 & $\mathrm{ND}$ & 0.09 & 0.35 & 0.28 & ND & ND & 9.32 & 9.24 \\
\hline $\mathbf{T}_{22}$ & 3.98 & 0.08 & ND & 0.16 & 0.38 & 0.31 & ND & $\mathrm{ND}$ & 9.28 & 9.22 \\
\hline $\mathbf{T}_{23}$ & 4.12 & 0.10 & ND & 0.34 & 0.48 & 0.32 & $\mathrm{ND}$ & 0.01 & 9.64 & 9.46 \\
\hline $\mathbf{T}_{24}$ & 3.44 & 0.09 & 0.01 & 0.28 & 0.32 & 0.18 & $\mathrm{ND}$ & 0.01 & 9.04 & 9.12 \\
\hline Min & 2.18 & 0.06 & NA & NA & 0.03 & 0.11 & NA & NA & 9.02 & 7.30 \\
\hline Max & 5.65 & 0.19 & 0.01 & 0.71 & 0.51 & 0.58 & 0.02 & 0.01 & 12.25 & 13.28 \\
\hline Median & 3.64 & 0.12 & 0.01 & 0.34 & 0.36 & 0.32 & 0.02 & 0.01 & 9.65 & 9.39 \\
\hline Mean & 3.70 & 0.12 & 0.01 & 0.33 & 0.33 & 0.32 & 0.02 & 0.01 & 9.96 & 9.97 \\
\hline SD & 0.67 & 0.04 & 0.00 & 0.21 & 0.12 & 0.12 & 0.01 & 0.00 & 0.94 & 1.40 \\
\hline
\end{tabular}

Table 4: Concentration of Heavy Metals of Tap-Water Samples Collected outside the Study Area in ppm.

\begin{tabular}{lllllllllll}
\hline Sample & $\mathbf{M g}$ & $\mathbf{M n}$ & $\mathbf{C u}$ & $\mathbf{Z n}$ & $\mathbf{F e}$ & $\mathbf{P b}$ & $\mathbf{C d}$ & $\mathbf{A g}$ & $\mathbf{A s}$ & $\mathbf{C r}$ \\
\hline $\mathbf{O T}_{\mathbf{1}}$ & 0.15 & ND & ND & 0.10 & ND & ND & ND & ND & 2.40 & 3.04 \\
$\mathbf{O T}_{\mathbf{2}}$ & 0.10 & ND & ND & 0.10 & ND & ND & ND & ND & 1.80 & 4.10 \\
$\mathbf{O T}_{3}$ & 0.18 & ND & ND & ND & 0.10 & ND & ND & ND & 2.60 & 1.68 \\
$\mathbf{O T}_{\mathbf{4}}$ & 0.14 & ND & ND & 0.20 & 0.10 & ND & ND & ND & 1.65 & 1.26 \\
$\mathbf{O T}_{\mathbf{5}}$ & 0.14 & ND & ND & 0.15 & ND & ND & ND & ND & 3.20 & 4.10 \\
$\mathbf{O T}_{\mathbf{6}}$ & ND & ND & ND & 0.10 & 0.10 & ND & ND & ND & 2.20 & 2.40 \\
Min & 0.10 & NA & NA & 0.10 & 0.10 & ND & NA & NA & 1.65 & 1.26 \\
Max & 0.18 & NA & NA & 0.20 & 0.10 & NA & NA & NA & 3.20 & 4.10 \\
Median & 0.14 & NA & NA & 0.10 & 0.10 & NA & NA & NA & 2.30 & 2.72 \\
Mean & 0.14 & NA & NA & 0.13 & 0.10 & NA & NA & NA & 2.31 & 2.76 \\
SD & 0.03 & NA & NA & 0.04 & NA & NA & NA & NA & 0.56 & 1.20 \\
\hline
\end{tabular}

NA $=$ Not Available

$\mathrm{ND}=$ Not Detectable 
Table 5: Current Drinking Water Quality Guidelines (in ppm Or Mg/L) for the Selected Heavy Metals.

\begin{tabular}{cccccccc}
\hline Elements & $\mathbf{W H O}^{\mathbf{a}}$ & $\mathbf{U S E P A}^{\mathbf{b}}$ & $\mathbf{E C E}^{\mathbf{c}}$ & $\begin{array}{c}\mathbf{F T P}^{\mathbf{C}} \\
\mathbf{C D W}^{\mathbf{d}}\end{array}$ & $\begin{array}{c}\text { PCRWR } \\
\mathbf{e}\end{array}$ & $\begin{array}{c}\text { ADW } \\
\mathbf{G}^{\mathbf{f}}\end{array}$ & $\mathbf{N O M - 1 2 7}^{\mathbf{e}}$ \\
\hline $\mathrm{Mg}$ & - & - & - & - & - & - & - \\
$\mathrm{Mn}$ & 0.100 & 0.050 & 0.050 & 0.050 & 0.500 & 0.500 & 0.150 \\
$\mathrm{Cu}$ & 2.000 & 1.300 & 2.000 & 1.000 & 2.000 & 2.000 & 2.000 \\
$\mathrm{Zn}$ & 5.000 & 0.500 & - & 5.000 & 5.000 & 3.000 & 5.000 \\
$\mathrm{Fe}$ & 1.000 & 0.300 & 0.200 & 0.300 & - & 0.300 & 0.300 \\
$\mathrm{~Pb}$ & 0.010 & 0.015 & 0.010 & 0.010 & 0.050 & 0.010 & 0.010 \\
$\mathrm{Cd}$ & 0.003 & 0.005 & 0.005 & 0.005 & 0.010 & 0.002 & 0.005 \\
$\mathrm{Ag}$ & 0.100 & 0.100 & - & - & - & 0.100 & - \\
$\mathrm{As}$ & 0.010 & 0.010 & 0.010 & 0.010 & 0.050 & 0.010 & 0.025 \\
$\mathrm{Cr}$ & 0.050 & 0.100 & 0.050 & 0.050 & 0.050 & 0.050 & 0.050 \\
\hline
\end{tabular}

SOURCE: a, World Health Organization (WHO, 2011); b, United Stated Environmental Protection Agency (USEPA, 2011); c, European Commission Environment (ECE, 1998); d, Federal-Provincial-Territorial Committee on Drinking Water (CDW), Health Canada (FTP-CDW, 2010); e, Pakistan Council of Research in Water (PCRWR, 2008); f, Australian Drinking Water Guidelines (ADWG, 2011); g, Norma Official Mexicana NOM-127-SSA1-1994 (DOF, 1994)

\section{Pearson Correlation Analysis}

The Pearson correlation coefficients between the heavy metals concentrations and MS values and between different elements are presented in Tables 4 and 5.

\begin{tabular}{|c|c|c|c|c|c|c|c|c|c|c|}
\hline Element & Mg & Mn & Ag & $\mathbf{Z n}$ & Cd & $\mathbf{P b}$ & $\mathrm{Cu}$ & $\mathbf{F e}$ & As & $\mathrm{Cr}$ \\
\hline Mg & 1 & NA & 0.353 & 0.327 & 0.126 & 0.118 & 0.789 & 0.780 & 0.913 & 0.495 \\
\hline Mn & & 1 & $\mathrm{NA}$ & NA & NA & $\mathrm{NA}$ & $\mathrm{NA}$ & NA & NA & NA \\
\hline Ag & & & 1 & 0.114 & 0.890 & 0.245 & 0.750 & 0.434 & 0.373 & 0.536 \\
\hline $\mathbf{Z n}$ & & & & 1 & 0.924 & 0.581 & 0.123 & 0.775 & 0.467 & 0.506 \\
\hline Cd & & & & & 1 & 0.908 & 0.176 & 0.591 & 0.259 & 0.798 \\
\hline $\mathbf{P b}$ & & & & & & 1 & 0.130 & 0.155 & 0.247 & 0.871 \\
\hline $\mathrm{Cu}$ & & & & & & & 1 & 0.645 & 0.838 & 0.599 \\
\hline $\mathbf{F e}$ & & & & & & & & 1 & 0.828 & 0.063 \\
\hline As & & & & & & & & & 1 & 0.241 \\
\hline $\mathrm{Cr}$ & & & & & & & & & & 1 \\
\hline \multicolumn{11}{|c|}{$\begin{array}{l}\text { NA }=\text { Not Available } \\
\text { ND }=\text { Not Detectable }\end{array}$} \\
\hline Element & Mg & Mn & Ag & $\mathbf{Z n}$ & Cd & $\mathbf{P b}$ & $\mathrm{Cu}$ & $\mathrm{Fe}$ & As & $\mathrm{Cr}$ \\
\hline Mg & 1 & 0.222 & 0.141 & 0.420 & 0.167 & 0.534 & $\mathrm{NA}$ & 0.321 & 0.590 & 0.556 \\
\hline Mn & & 1 & 0.327 & 0.084 & 0.127 & 0.251 & 0.255 & 0.588 & 0.543 & 0.706 \\
\hline Ag & & & 1 & 0.329 & NA & 0.760 & NA & 0.456 & 0.972 & 0.940 \\
\hline $\mathbf{Z n}$ & & & & 1 & 0.114 & 0.141 & 0.577 & 0.145 & 0.385 & 0.288 \\
\hline Cd & & & & & 1 & 0.760 & NA & 0.283 & 0.972 & 0.940 \\
\hline $\mathbf{P b}$ & & & & & & 1 & 0.760 & 0.415 & 0.889 & 0.933 \\
\hline $\mathrm{Cu}$ & & & & & & & 1 & 0.871 & 0.972 & 0.940 \\
\hline $\mathrm{Fe}$ & & & & & & & & 1 & 0.326 & 0.617 \\
\hline As & & & & & & & & & 1 & 0.994 \\
\hline $\mathrm{Cr}$ & & & & & & & & & & 1 \\
\hline
\end{tabular}

NA $=$ Not Available

$\mathrm{ND}=$ Not Detectable 


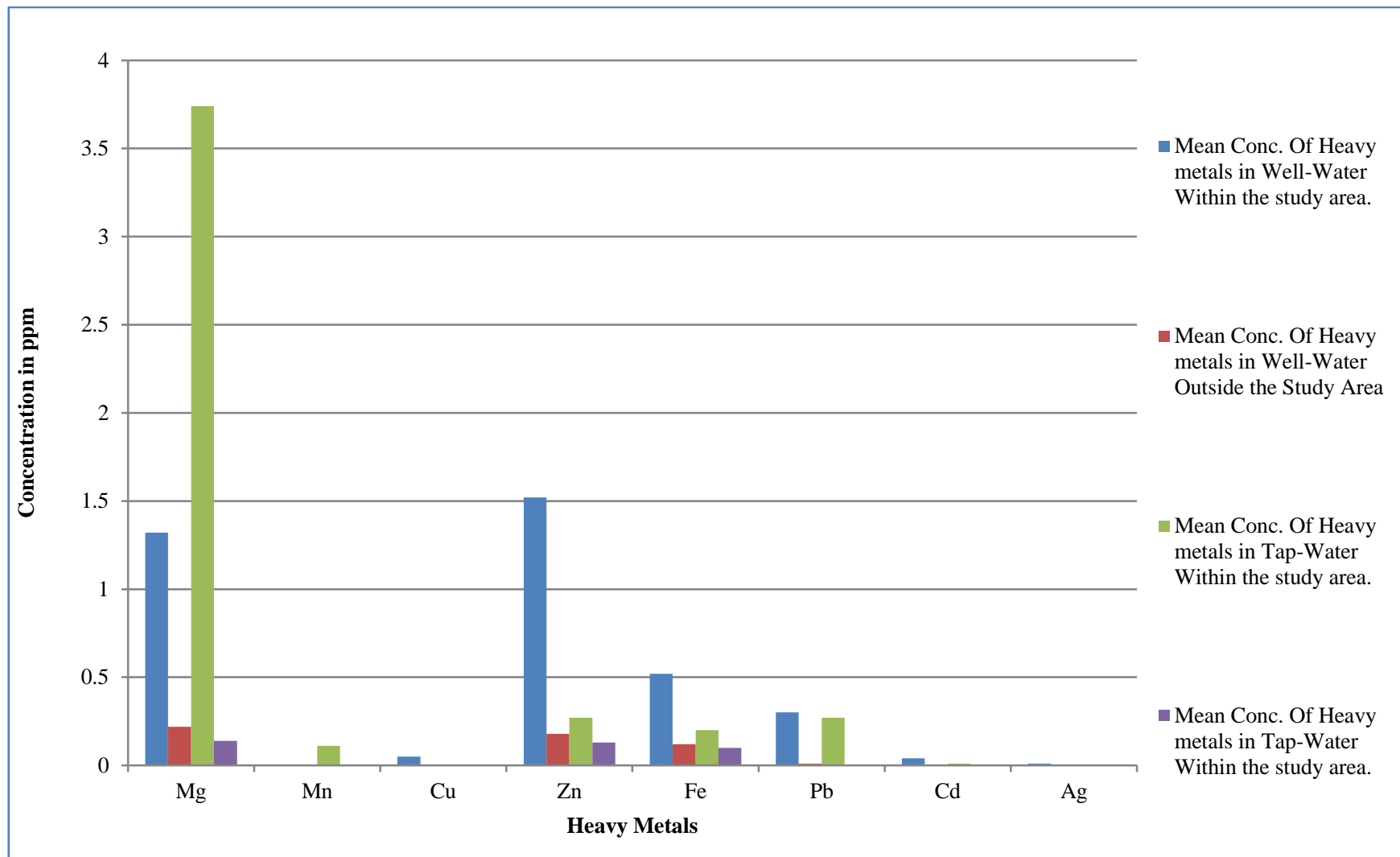

Figure 2: Mean concentration of selected heavy metals in well-water and tap-water within and outside the study area.

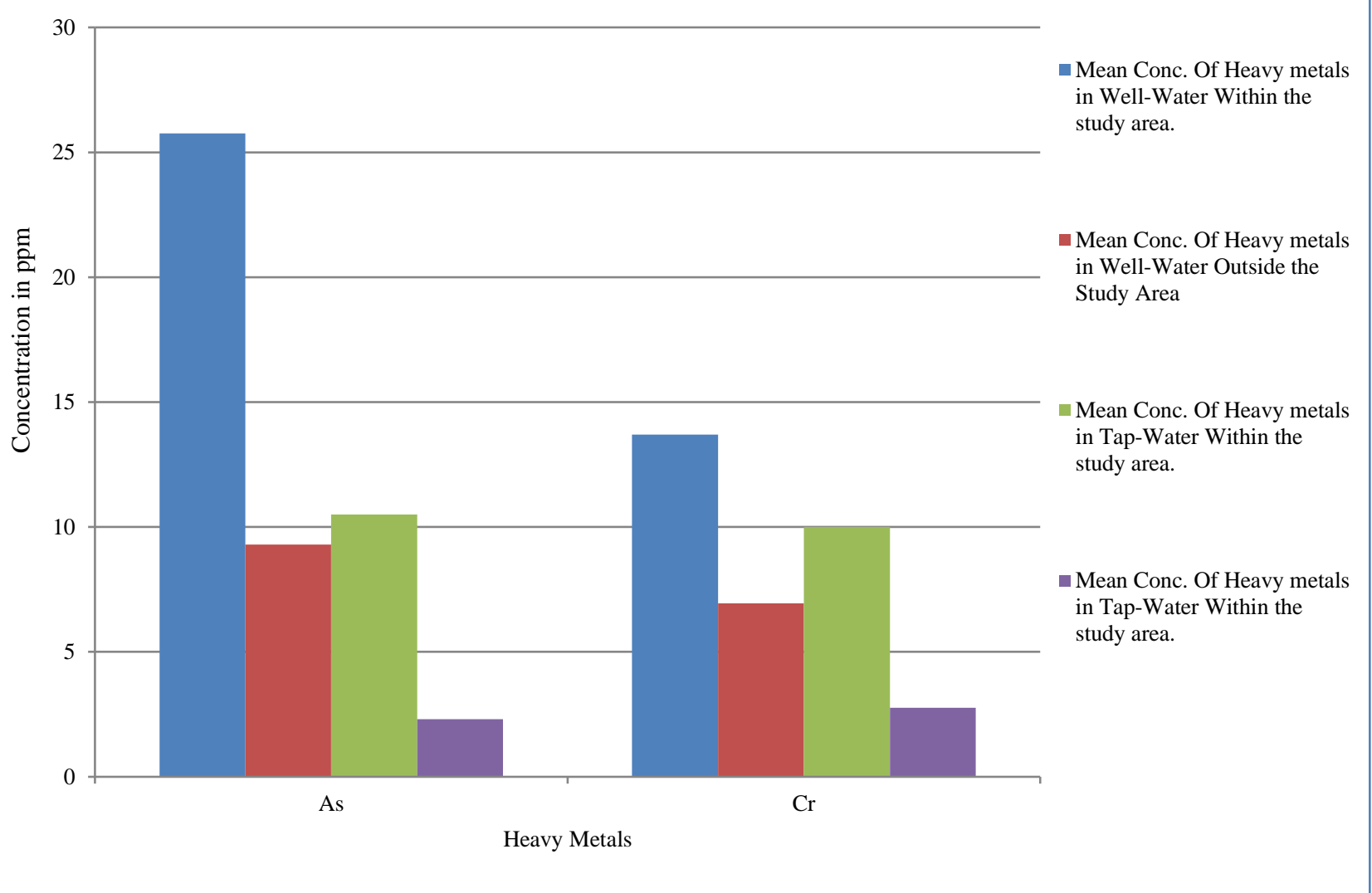

Figure 3: Mean concentration of As and $\mathrm{Cr}$ in well-water and tap-water within and outside the study area. 


\section{DISCUSSION}

The mean concentrations of As within the study area are 24.44 and $9.96 \mathrm{ppm}$ for well and tap water respectively while the mean concentrations outside the area are 9.30 and $2.31 \mathrm{ppm}$ for well and tap water respectively. These values are well above the WHO recommended limit for consumption. This could lead to Arsenic poisoning if consumed over a long period of time. Symptoms of arsenic poisoning begin with headaches, confusion, severe diarrhea, and drowsiness. As the poisoning develops, convulsions and changes in fingernail pigmentation called leukonychiastriata may occur. When the poisoning becomes acute, symptoms may include diarrhea, vomiting, blood in the urine, cramping muscles, hair loss, stomach pain, and more convulsions (Tseng et al., 2003; smith et al., 1992).

The organs of the body that are usually affected by arsenic poisoning are the lungs, skin, kidneys, and liver. The final result of arsenic poisoning is coma and death. For $\mathrm{Cr}$ within the study area the mean concentrations are 14.32 and $9.97 \mathrm{ppm}$ for well and tap water respectively while the mean concentrations outside the area are 6.94 and $2.76 \mathrm{ppm}$ for well and tap water respectively. These values too exceeds the WHO permitted limit in drinking water. It has been reported that long term exposure to $\mathrm{Cr}$ can cause damage to liver, kidney circulatory and nerve tissues, as well as skin irritation (Tseng et al., 2003; smith et al., 1992). For Zn within the study area the mean concentrations are 1.54 and $0.33 \mathrm{ppm}$ for well and tap water respectively while the mean concentrations outside the area are 0.18 and $0.13 \mathrm{ppm}$ for well and tap water respectively.

The permissible limit of zinc in water according to WHO standards is $5 \mathrm{ppm}$. In all the collected water samples concentration of zinc was recorded below the permissible limit. For $\mathrm{Mg}$ within the study area the mean concentrations are 1.43 and 3.70 ppm for well and tap water respectively while the mean concentrations outside the area are 0.22 and $0.14 \mathrm{ppm}$ for well and tap water respectively. For Fe within the study area the mean concentrations are 0.64 and $0.33 \mathrm{ppm}$ for well and tap water respectively while the mean concentrations outside the area are 0.12 and $0.10 \mathrm{ppm}$ for well and tap water respectively. Excess amount of iron (more than $10 \mathrm{ppm}$ ) is reported to causes rapid increase in pulse rate and coagulation of blood in blood vessels, hypertension and drowsiness (Adepoju-Bello and Alabi, 2005; WHO, 2008; Lawrence, 2014).

In all the collected water samples, the concentration of $\mathrm{Fe}$ is below the $1.00 \mathrm{ppm}$ the permissible limit according to WHO. For $\mathrm{Pb}$ within the study area the mean concentrations are 0.25 and $0.32 \mathrm{ppm}$ for well and tap water respectively while the mean concentration outside the area is $0.10 \mathrm{ppm}$ for well water and below the detectable limit for tap water. Lead is a commutative poison and a possible human carcinogen. The concentration of $\mathrm{Pb}$ is above the permissible limit in drinking water, so people consuming the water should be worried of its bioaccumulation over time as higher concentrations of $\mathrm{Pb}$ can even cause irreversible brain damage (Bakare-Odunola, 2005; WHO, 2008; Lawrence, 2014). In addition, Lead may cause the development of autoimmunity in which a person's immune system attacks its own cells. This can lead to joint diseases and ailment of the kidneys, circulatory system and neurons (Bakare-Odunola, 2005).

For Cd within the study area the mean concentration is 0.05 and $0.02 \mathrm{ppm}$ for well and tap water respectively while the mean concentration outside the area is below detectable limit for both well and tap water. Cadmium exposure produces kidney damage and hypertension. For $\mathrm{Cu}$ within the study area, the mean concentration is 0.05 and $0.01 \mathrm{ppm}$ for well and tap water respectively while the mean concentration outside the area is below detectable limit for both well and tap water. For $\mathrm{Ag}$ within the study area, the mean concentration is 0.02 and $0.01 \mathrm{ppm}$ for well and tap water respectively while the mean concentration outside the area is below the detectable limit for both well and tap water. And for Mn within the study area, the mean concentration is below detectable limit for well water and $0.02 \mathrm{ppm}$ tap water while the mean concentration outside the area is below the detectable limit for both well and tap water.

For the well-water samples within the study area, the result show that the mean concentration of the heavy metals decreases in the order $\mathrm{As}>\mathrm{Cr}>\mathrm{Zn}>\mathrm{Mg}>\mathrm{Fe}>\mathrm{Pb}>\mathrm{Cd}>$ $\mathrm{Cu}>\mathrm{Ag}>\mathrm{Mn}$ while that of the tap-water is in order $\mathrm{As}>\mathrm{Cr}$ $>\mathrm{Mg}>\mathrm{Zn}>\mathrm{Pb}>\mathrm{Fe}>\mathrm{Mn}>\mathrm{Cd}>\mathrm{Ag}>\mathrm{Cu}$ (see figures 2 and 3 ). These mean concentrations within the study area are much higher than the mean concentrations outside the study. This implies that the concentration of these selected heavy metals is enhanced by the mining activities. The concentrations of Arsenic (As) and Chromium (Cr) in both well and tap water are much higher than other selected heavy metals. This may partly be due to the local geology of the study area as higher values were evident even outside the study area and also due to the fact that Arsenic can be recovered from processing of ores containing mostly copper, lead, zinc, silver and gold. It is also present in ashes from coal combustion. Also, Arsenates can be leached easily if the amount of reactive metal in the soil is low (Smith et al., 1995; UNEP, 1997; Lawrence, 2014).

Arsenic (V) can also be mobilized under reducing conditions that encourage the formation of Arsenic (III), under alkaline and saline conditions, in the presence of other ions that compete for sorption sites, and in the presence of organic compounds that form complexes with arsenic (Smith et al., 1995; Barakat et al., 2012). Major sources of Cr contamination include releases from electroplating processes and the disposal of chromium containing wastes (Smith et al., 1995; UNEP, 1997; McMurry and Fay, 2004; Mendie, 2005). This explains the enhanced Chromium concentrations observed within the study area as soluble and unadsorbed chromium complexes can leach from soil into groundwater (Smith et al., 1995; McMurry and Fay, 2004; Mendie, 2005; Yu et al., 2014).

Expectedly, the concentration of some of the metals investigated is higher than their maximum permissible limit for consumption (see Table 3). Study by the United States Food and Drug Administration and Control (2003) and United Nations Environment Program (1997) reveals similar observations. For the well-water samples, $\mathrm{As}, \mathrm{Cr}, \mathrm{Pb}, \mathrm{Cd}$, and $\mathrm{Mg}$ have their mean concentrations higher than their permissible limit for consumption. Similar result was observed in tap-water samples. 
The correlation analysis between the selected heavy metals was conducted, the results were classified according to the correlation coefficient $\mathrm{r}(\mathrm{Yu}$ and $\mathrm{Hu}, 2005)$, as follows:

$0.8 \leqslant|\mathrm{r}| \leqslant 1$ suggests a strong correlation;

$0.5 \leqslant|\mathrm{r}|<0.8$ suggests a significant correlation;

$0.3 \leqslant|\mathrm{r}|<0.5$ suggests a weak correlation; and

$|r|<0.3$ suggests an insignificant correlation. The resulting correlation analysis for well-water demonstrated that $\mathrm{Zn} / \mathrm{Cd}(\mathrm{r}$ $=0.942), \mathrm{As} / \mathrm{Mg}(\mathrm{r}=0.913), \mathrm{Cd} / \mathrm{Pb}(\mathrm{r}=0.908), \mathrm{Ag} / \mathrm{Cd}(\mathrm{r}=$ $0.890), \mathrm{Pb} / \mathrm{Cr}(\mathrm{r}=0.871), \mathrm{Cu} / \mathrm{Fe}(\mathrm{r}=0.838)$ and Fe/As $(\mathrm{r}=$ $0.828)$ were strongly correlated whereas $\mathrm{Cd} / \mathrm{Cr}(\mathrm{r}=0.798)$, $\mathrm{Mg} / \mathrm{Fe}(\mathrm{r}=0.789), \mathrm{Mg} / \mathrm{Cu}(\mathrm{r}=0.780), \mathrm{Zn} / \mathrm{Fe}(\mathrm{r}=0.775)$, $\mathrm{Ag} / \mathrm{Cu}(\mathrm{r}=0.750), \mathrm{Cu} / \mathrm{Fe}(\mathrm{r}=0.645)$ and $\mathrm{Cu} / \mathrm{Cr}(\mathrm{r}=0.599)$ gives significant correlation while others shows insignificant correlation. Similar result were observed in tap-water (see Tables 4 and 5). This follows that the selected heavy metals have common pollution source believed to be related to the process of mineral extraction, processing, smelting and refining activities at the study area.

\section{CONCLUSION}

The results of this study show that the concentration of some of the metals investigated is higher than their maximum permissible limit for consumption. For the well-water samples within the study area, the result shows that the mean concentration of the heavy metals decreases in the order As > $\mathrm{Cr}>\mathrm{Zn}>\mathrm{Mg}>\mathrm{Fe}>\mathrm{Pb}>\mathrm{Cd}>\mathrm{Cu}>\mathrm{Ag}>\mathrm{Mn}$ while that of the tap-water is in order $\mathrm{As}>\mathrm{Cr}>\mathrm{Mg}>\mathrm{Zn}>\mathrm{Pb}>\mathrm{Fe}>\mathrm{Mn}>$ $\mathrm{Cd}>\mathrm{Ag}>\mathrm{Cu}$. These mean concentrations within the study area are much higher than the mean concentrations outside the study area. This implies that the concentration of these selected heavy metals is enhanced by the mining activities. Hence, the Well and Tap water are significantly affected by the process of mineral extraction, processing, smelting and refining activities at the study area.

Therefore, it is recommended that mining companies should treat their wastes by precipitating out metals thus reducing their mobility through seepage. Construction of ponds with adequate retention times that can enhance the removal and retention of metals is also suggested.

\section{ACKNOWLEDGEMENTS}

The authors would like to express their sincere gratitude to the staff of ROTAS Soil Laboratory, Ibadan for the Atomic Absorption Spectrometry.

\section{REFERENCES}

Adepoju-Bello, A.A. and Alabi, O.M. (2005). Heavy metals: A review. The Nig. J. Pharm., 37: 41-45.

Adepoju-Bello, A.A.; O. Ojomolade, G. Ayoola, and H. Coker. (2009). Quantitative analysis of some toxic metals in domestic water obtained from Lagos metropolis. The Nig. J. Pharm. 42(1): 57-60.
Adeyemi, O.; O. Oloyede, and A. Oladiji. (2007). Physicochemical and microbial characteristics of Leachate contaminated ground water. Asian J. Biochem., 2(5): 343-348.

Australian Drinking Water Guidelines (ADWG) (2011). Australian drinking water guideline 2011. Retrieved from

http://www.nhmrc.gov.au/_files_nhmrc/publications/attachm ents/eh52_aust_drinking_water_ guidelines.pdf (Verified November 15, 2011).

Bader, N. R. (2011). Sample Preparation for Flame Atomic Absorption Spectroscopy: An Overview Rasayan Journal of Chemistry 414955.

Bakare-Odunola, M.T. (2005). Determination of some metallic impurities present in soft drinks marketed in Nigeria. The Nig. J. Pharm., 4(1): 51-54.

Barakat, A.; M. El Baghdadi, J. Rais, and S. Nadem. (2012). Assessment of Heavy Metal in Surface Sediments of Day River at Beni-Mellal Region, Morocco. Research Journal of Environmental and Earth Seiences. 4 (8): 797-806

DiarioOficial de la Federación (DOF) (1994). Norma Oficial Mexicana NOM-127-SSA1-1994. Retrieved from http://bibliotecas.salud.gob.mx/gsdl/collect/nomssa/index/ass oc/HASH015a.dir/doc.pdf\#search="[agua]:DC" ＂Verified November 15, 2011).

European Commission Environment (ECE) (1998). Council Directive 98/83/EC of 3 November 1998. Retrieved from http://eur-ex.europa.eu/LexUriServ/LexUriServ.do?uri= OJ:L:1998:330:0032:0054:EN: PDF (Verified November 15, 2011).

Federal-Provincial-Territorial Committee on Drinking Water, Health Canada (FTP-CDW) (2010). Guidelines for Canadian Drinking Water Quality. Retrieved from http://www.hc-sc.gc.ca/ewh-semt/alt_formats/hecs-sesc /pdf/pubs/water-eau/2010-sum_guide-res_recom/sum_guideres_recom-eng.pdf (Verified November 15, 2011).

Lawrence. W. (2014): Toxic Metals and Detoxification, The Center for Development Inc. retrieved July 5, 2014 fromhttp://www.drlwilson.com/articles/TOXIC\%20METALS .htm

Marcovecchio. J.; S. Botte, and R. Freije. (2007). Heavy Metals, Major Metals, Trace Elements. In: Handbook of Water Analysis. L.M. Nollet, (Ed.). 2ndEdn. London: CRC Press, 275-311.

McMurry, J. and Fay, R. (2004). Hydrogen, Oxygen and Water. In: McMurry Fay Chemistry. K.P. Hamann, (Ed.). 4th Edn. New Jersey: Pearson Education, 575-599.

Mendie, U. (2005). The Nature of Water. In: The Theory and Practice of Clean Water Production for Domestic and Industrial Use. Lagos: Lacto-Medals Publishers, 1-21.

Nwankwo L.I. (2013). Study of Natural Radioactivity of Ground water in Sango-Ilorin. Nigeria. Journal of Physical Science and Application, 2 (8): 289-295.

Olukanni, D. O. and Kokumo, K. O. (2013) Efficiency Assessment of a Constructed Wetland Using Eichhornia Crassipes for Wastewater Treatment. American Journal of Engineering Research (AJER), 2 (12): 450-454.

Olukanni, D. O.; M.A. Ebuetse, and W.U. Anake. (2014). Drinking Water Quality and Sanitation Issues: A 
Survey of a Semi-Urban Setting in Nigeria. International Journal of Research in Engineering and Science, 2 (11): 58-65.

Pakistan Council of Research in Water Resources (PCRWR) (2007). National Standards for Drinking Water Quality (NSDWQ) June, 2008. Retrieved from http://www.environment.gov.pk/act-rules/DWQStd-

MAY2007.pdf (Verified November 15, 2011)

Pakistan Council of Research in Water Resources (PCRWR) (2008). National Water Quality Monitoring Program. Water Quality Report 2003-2004. Islamabad, Pakistan: Pakistan Council of Research in Water Resources. http://www.pcrwr.gov.pk/wq_phase3_report/TOC.htm. (Verified June 1, 2011).

Smith A. H.; C. Hopenhayn-Rich, and M.N. Bates. (1992): Cancer risks from arsenic in drinking water. Environ. Health Perspect.97: 259-67. doi:10.2307/3431362. PMC 1519547. PMID 1396465.

Tseng C.H.; C.K. Chong, and C.P. Tseng. (2003). Long-term arsenic exposure and ischemic heart disease in arseniasis-hyperendemic villages in Taiwan. Toxicol. Lett.137 (1-2): 15-21.

UNICEF/WHO (2011) Drinking Water Equity, Safety and Sustainability: Thematic report on drinking water World Health Organization 2010 Water for Health; World Health Organizational Standard Guidelines for Drinking-water Quality, volume 1

United Nations Environment Program (UNEP) (1997). Industry and environment, mining and sustainable development. Available at

http//www.uneptie.org/vol20no4.htm. Accessed (16/11/2015).

United Stated Environmental Protection Agency (USEPA) (1986). 'Acid Digestion of Sediment, Sludge and Soils', in USEPA (ed.), Test Methods for Evaluating Soil Waste SW-846, USEPA, Cincinnati, OH, U.S.A.
United Stated Environmental Protection Agency (USEPA) (2011). National Primary Drinking Water Regulations. Retrieved from http://water.epa.gov/drink/contaminants/index.cfm\#List (Verified November 15, 2011).

United States Food and Drug Administration (2003). Heavy metals analysis in food and non- food substances, American Journal of Science, 85: 3 - 7.

Vanloon. G., and Duffy. S. (2005). The Hydrosphere. In: Environmental Chemistry: A Global Perspective. 2nd Edn. New York: Oxford University Press, pp: 197-211.

Vodela, J., Renden. J., Lenz. S., MchelHenney. W., and Kemppainen. B. (1997). Drinking water contaminants. Poult. Sci., 76: 1474-1492.

World Health Organization (WHO) (2008). Guidelines for drinking-water quality [electronic resource]: incorporating 1st and 2nd addende, 3rd Ed., Recommendations. Geneva. $1: 515$

World Health Organization (WHO) (2011). Guidelines for drinking-water quality, fourth edition. Retrieved from http://whqlibdoc.who.int/publications/2011/9789241548151_ eng.pdf (verified November 15, 2011)

World Health Organization and United Nations Children's Fund (2012) Progress on Drinking Water and Sanitation 2012 Update.

Yu, L.; Z. Renguang, and Y. Mingguo. (2014). The relationships between magnetic susceptibility and elemental variations for mineralized rocks. Journal of Geochemical Exploration 146 (2014) 17-26.

Yu, J.; and Hu, X. (2005). Application of data statistical analysis with SPSS. Post \& Telecom Press, Beijing, pp. 163173. 